\title{
FUNCTIONAL SPACES AND FURNISHING DESIGNS IN THE HISTORICAL ANATOLIAN SELJUK AND OTTOMAN HOSPITALS
}

\author{
GÜLŞEN DİŞLI* \\ Department of Architecture, Necmettin Erbakan University, Turkey
}

\begin{abstract}
Understanding of working principles, conceptual designs and specific characteristics of the functional spaces in historical hospitals is vitally important for improving proper maintenance and preservation programs by which survival of those buildings could be achieved for the sake of next generations. Properly determining of such functional spaces ranging from patients' rooms, pharmacy, policlinics, latrines, surgery rooms, baths to kitchens regards several comprehensive studies. However, there are only a few studies conducted on the determination of functional spaces in the Anatolian Seljuk and Ottoman hospitals. Furthermore, there is no any specific study yet carried out on how those spaces developed, and on their original furnishing designation. Therefore, this article first aims to portray different functions of the spaces located in the Anatolian hospitals built from the thirteen to eighteen centuries. Portraying of the functional spaces includes examination of their construction history, original furnishing designs and interior fittings as well. As a matter of fact, all those spaces collectively reflect their regional features and developmental stage of their own period. By using an extensive collection of evaluations on functional spaces from twelve historical Seljuk and Ottoman hospitals, this article includes some comparative studies of common and uncommon features of historic hospitals in these two periods in terms of their functional spaces and furnishing design by using primary and secondary sources, together with in-situ observations. Thus, the research also reveals the similarities and differences as well as periodic developments of original functional spaces and their furnishing designs in historical hospitals between Seljuk and Ottoman periods. Furthermore, the research showed that travellers' accounts, waqf deeds, old pictures, and gravures by which several valuable information on original furnishing of hospital spaces could be obtained. By this study it is clearly revealed that while some of the functional spaces designed in the Seljuk period lost their function, many others were added into Ottoman's hospitals with an increasing variety of spaces designed nearly for all functions.

Keywords: historic hospitals, Anatolia, Seljuk and Ottoman periods, functional spaces, furnishing, interior fittings.
\end{abstract}

\section{INTRODUCTION}

During the Seljuk and the Ottoman periods hospitals of Anatolia were mostly built upon the orders of Sultans, their wives, daughters or by wealthy people in order to serve for the patients in need. Both in Seljuk and Ottoman period, it was common to care for the patients at their own home by their families except for the insane ones and for the patients with contagious diseases. Physicians visited to the houses only if any patient had a serious disease (Fig. 1). Yet, patients with no family, strangers of the city, poor people, travellers, explorers, merchants coming from long trading journeys were also treated in those hospitals without any charge when they were in need of health services [1]. Patients were welcomed to the hospitals by doorkeepers, cleaned in bath, and were given clean clothes before they were hospitalized [1]. For any research carried out on the original functional spaces and furnishing designs practised in the Anatolian Seljuk and the Ottoman hospitals, which is the primary

*ORCID: https://orcid.org/0000-0003-2620-0492 


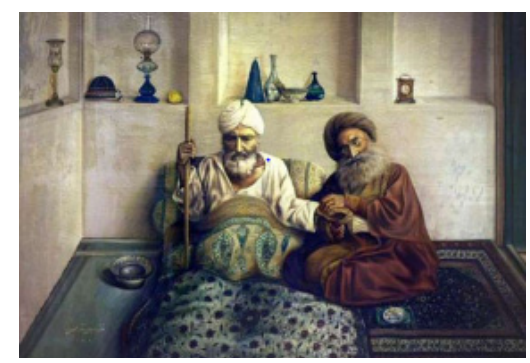

Figure 1: Painting of Mehdi Musavver el-melek depicting an old patient at his home and a physician treating his illness, Tahran, 1309 h. K/ 1891 [2].

focus of this study, it is very crucial to well understand and clearly analyses peculiar functions of those hospital spaces, and thus any e technical transfer from the historical design strategies to today's modern buildings might be possible.

\section{ANALYSIS OF FUNCTIONAL SPACES IN THE ANATOLIAN SELJUK AND THE OTTOMAN HOSPITALS}

Although there is lots of information on architecture of historical hospitals, data on the functional space analysis for these buildings is rather limited. Among them Cantay's noticeable research first published in 1992 includes several detailed historical and architectural description and drawings of Anatolian Seljuk and Ottoman period hospitals [3]. In addition, historical court registers, travellers' accounts, old drawings, photographs, gravures, waqf deeds, as well as research excavations and in situ observations have been the primary sources used during this study. In waqf deeds belonging to the hospitals, the official staff and their duties were explained in a detailed manner. Hence, it is certain that the staff had to work in various related spaces in their hospitals according to terms of references specified in the waqf deeds of the hospitals [4], [5]. Thus, by using the data in the waqf deeds related to staff it has been possible to determine the functional spaces in the historical hospitals being studied. During the determination of functions and possible locations of each space in each hospital, the data has been compiled in accordance with reliability degree by using primary and secondary sources. Primary functional spaces detected in those Seljuk and Ottoman hospitals have been classified as "treatment spaces", "spaces related to pharmacy", "education spaces", "service spaces", "administrative spaces", and "other functional spaces" [4], [5].

All the Ottoman period hospitals being studied within the context of this study were constructed as part of a mosque complex in big cities such as Bursa, Edirne, and Istanbul, which were once the capital of Ottoman Empire in different periods [4]-[6]. Among them only the Manisa, Hafsa Sultan Hospital differs from the others in this sense. In cities having hospitals from Seljuk period, Ottomans did not construct any, instead they used already built ones or built only some additions when necessary. The hospitals were also located in the big centres along the trade routes [6]. This preference can be explained in the context of past civilizations' socio-economic priorities, or the priority was given especially to the big crowded cities which had no hospitals yet [4], [5]. Primary functional spaces detected in those hospitals are; courtyard, patients' rooms, policlinic, office rooms, rooms for medicine students, classrooms, surgery rooms, pharmacy, pharmaceutical store, drug preparation room, bakery room, kitchen, bath, and latrine. Among them, policlinics, surgery rooms, and patients' rooms have been classified as "treatment spaces", pharmacy, pharmaceutical stores, 


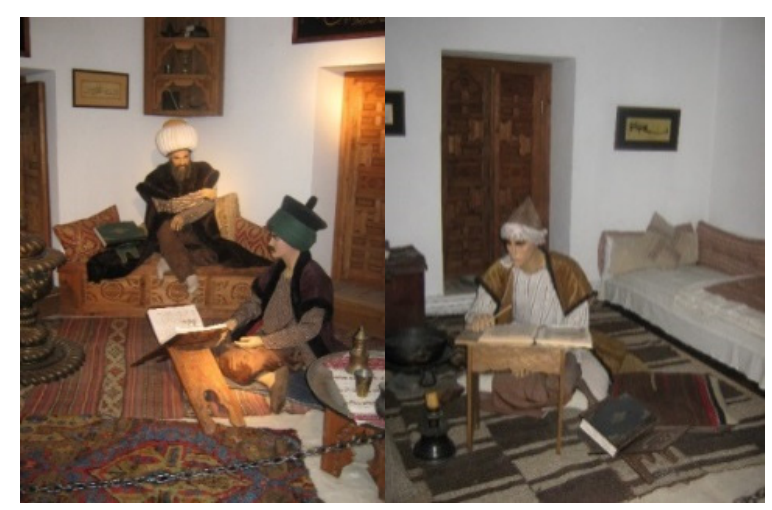

Figure 2: Illustrations of a teacher's room and a student's room in madrasah section of the Edirne II. Bayezid Hospital [7].

and drug preparation rooms as "spaces related to pharmacy", classrooms, rooms for medicine students and teachers' rooms as "education spaces", bakery, kitchen, bath, toilet, courtyard, and cellar as "service spaces", doctors' rooms, and office rooms as "administrative spaces", and finally tomb, masjid, stables, stores, and personnel lodges have been classified as "other functional spaces". Similarly, possible functions of spaces in the medicine madrasahs have been determined as students' rooms, teachers' rooms, iwan/summer classroom, winter classroom, tomb, masjid, and latrine [4], [5] (Fig. 2).

During the transition period from the Anatolian Seljuk to the Ottoman era some notable changes have been observed in the role of some functional spaces of the hospitals As an instance, main iwan, and side iwans, designed as semi-open spaces for the patients, as well as tombs located in Seljuk period hospitals have never been observable in the Ottoman ones. For instance, Divriği Melike Turan Hospital, Kayseri Gevher Nesibe Sultan Hospital and Medicine Madrasah and Sivas I. İzzettin Keykavus Hospital, all from the Seljuk period, have a tomb section inside the hospital premises. Instead, iwans of Seljuk period hospitals converted to patients' waiting halls/rooms and tombs were designed as part of the mosque complex as an independent unit in Ottoman hospitals. Similarly, masjid spaces were often designed at the same space with the tombs in Seljuk period, but instead they were designed as separate spaces located in related mosque complex in Ottoman period.

Because of some increasing demands and technological developments in time, different spaces were designed for the purpose of fulfilling new and different functions in Ottoman hospitals [4]. Bakery, summer and winter rooms for patients, and staff quarters are examples for new functional space developments for different needs in Ottoman hospitals (Table 1). Furthermore, there were several examples in the changing role of some functional spaces during the transition period, such as the niches used for the treatment of patients in Divriği Melike Turan Hospital of Seljuk period, turned into summer room for patients in Edirne II. Bayezid Hospital of Ottoman period (Fig. 3). Similarly, patients' waiting rooms/halls of Seljuk period, mostly designed as a closed space, were arranged as semi-open spaces in front of policlinics in Ottoman period hospitals, examples of which can be seen in Fatih, Haseki Sultan and Edirne II. Bayezid Hospitals. In addition, while hospitals' courtyards were also used as laundry in Seljuk period, separate spaces were designed for this function during the Ottoman period, as in Edirne II. Bayezid Hospital and Atik Valide Sultan Hospital. 


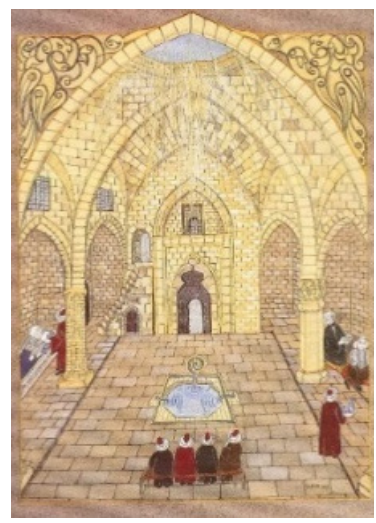

Figure 3: Illustration of the Divriği Melike Turan showing patient treatment scenes on the niches in front of the rooms. (Drawn by Ulker Erke [8].)

Locations of different functional spaces inside the hospitals also show some differences and developments in due course. As an instance, although the rooms on the left and right sides of the entrance were often used as policlinics in Seljuk period hospitals, in Ottoman period, policlinic rooms were often located around a separate courtyard with waiting halls in front, as clearly seen in Edirne II. Beyazıd Hospital. It is possible to explain this situation as an increasing need for the rearrangement of functional spaces because of the increase in different specialization in medicine. Such a location arrangement is also observable in Haseki Sultan Hospital, and Fatih Hospital. Rooms/wards for the insane were separated from the patient treatment rooms in both periods; for instance, in the Kayseri Gevher Nesibe Sultan Hospital, ward for the insane was located along a separate hall, in a similar vein in the Suleymaniye Hospital it was located on the basement floor and in the Edirne II. Bayezid Hospital, those rooms for the mental patients were located in a separate courtyard [4]. Patients rooms, on the other hand have been generally located around a courtyard behind the colonnaded porticos in both periods. In the Edirne II. Bayezid Hospital those rooms have been designed as summer and winter rooms around a separate courtyard. Heating, ventilation, refrigeration, waste and clean water, and drainage systems of hospitals also remarkably affected the functional space developments in those buildings [4]. For instance, construction of baths inside the hospitals, connecting the toilets to the city sewage network, wall fountains, pools, and wells inside the hospitals, fireplaces of patients' rooms and their chimney extensions are some indicators of relationship between functional spaces and systems [4]. During the analysis of original functional spaces of hospitals, it was difficult to differentiate the original locations of toilets, cellars, and baths. Hence, primary sources such as old drawings and waqf deeds have been used in order to determine the possible original location of those spaces. For instance, by examining the waqf deed of Haseki Hospital, it became possible to determine that there must have been a separate bath space inside the hospital, which is not existent today, since a bath attendant had been mentioned among the staff of the hospital in its waqf deed [9]. During the restoration of the hospital in 2011, this possible bath space was able to be detected by means of excavations. Terracotta pipes on the wall surfaces and water storage depot strengthen the argument of this thesis [4], [5].

In Ottoman period, it is also possible to mention about an hierarchy between the staff and the space allocated for them [4]. For instance, in Suleymaniye Hospital, administrative 
spaces, treatment spaces, and service spaces have been located along different separate courtyards. A similar hierarchical differentiation in locations is also observable in the Edirne II. Bayezid Hospital. However, in Seljuk hospitals such an hierarchical design is observable between treatment and education spaces as seen in the Kayseri Gevher Nesibe Sultan Hospital and the Medicine Madrasah. Similarly, in the Divriği Melike Turan Hospital, treatment and education spaces have been located on separate floors. In this sense, functional spaces have been examined in six different headings: treatment spaces, education spaces, spaces related to pharmacy, administrative spaces, service spaces and other functional spaces. In Fig. 4 and Table 1, findings obtained from the analysis of functional spaces in the Anatolian Seljuk and the Ottoman Period hospitals have been outlined. Among those functional spaces, preparatory rooms for surgery, patient treatment niches, installation rooms, tombs, and guest rooms were detected only in Seljuk period hospitals. On the other hand, summer rooms for patients, bakery, staff quarters, patients' waiting rooms/halls, kitchen, and laundry was observable only in the Ottoman period (Table 1). Patients' rooms, policlinics, and toilets have been similarly located in both periods.

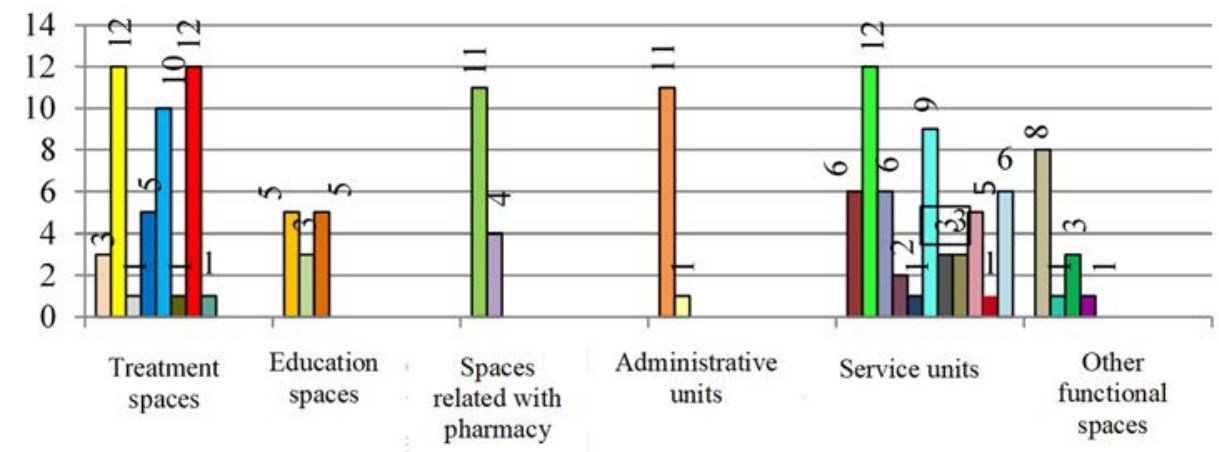

Possible Functional Spaces

$\begin{array}{ll}\text { Treatment spaces: } & \text { Service spaces: } \\ \square \text { Rooms/ward for the insane } & \square \text { Bath } \\ \square \text { Patient's room } & \square \text { Latrine } \\ \square \text { Summer room for patients } & \square \text { Doorkeeper's room } \\ \square \text { Summer classroom (polyclinic) } & \square \text { Laundry } \\ \square \text { Operating room } & \square \text { Installation room } \\ \square \text { Preparatory room for surgery } & \square \text { Cellar } \\ \square \text { Polyclinic } & \square \text { Patient's waiting room } \\ \square \text { Patient treatment niches } & \square \text { Patient's waiting hall } \\ \text { Spaces related with pharmacy: } & \square \text { Kitchen } \\ \square \text { Pharmacy } & \square \text { Bakery } \\ \square \text { Drug preparation room } & \square \text { Water storage depot/room } \\ \text { Education spaces: } & \text { Other functional spaces: } \\ \square \text { Student's rooms } & \square \text { Masjid } \\ \square \text { Teacher's rooms } & \square \text { Staff quarters } \\ \square \text { Winter classroom } & \square \text { Tomb } \\ \text { Administrative spaces: } & \square \text { Guest room } \\ \square \text { Doctor's room } & \\ \square \text { Other administrative staff rooms } & \end{array}$

Figure 4: Graphic showing distribution of spaces in Anatolian Seljuk and Ottoman Period hospitals being studied [5]. 


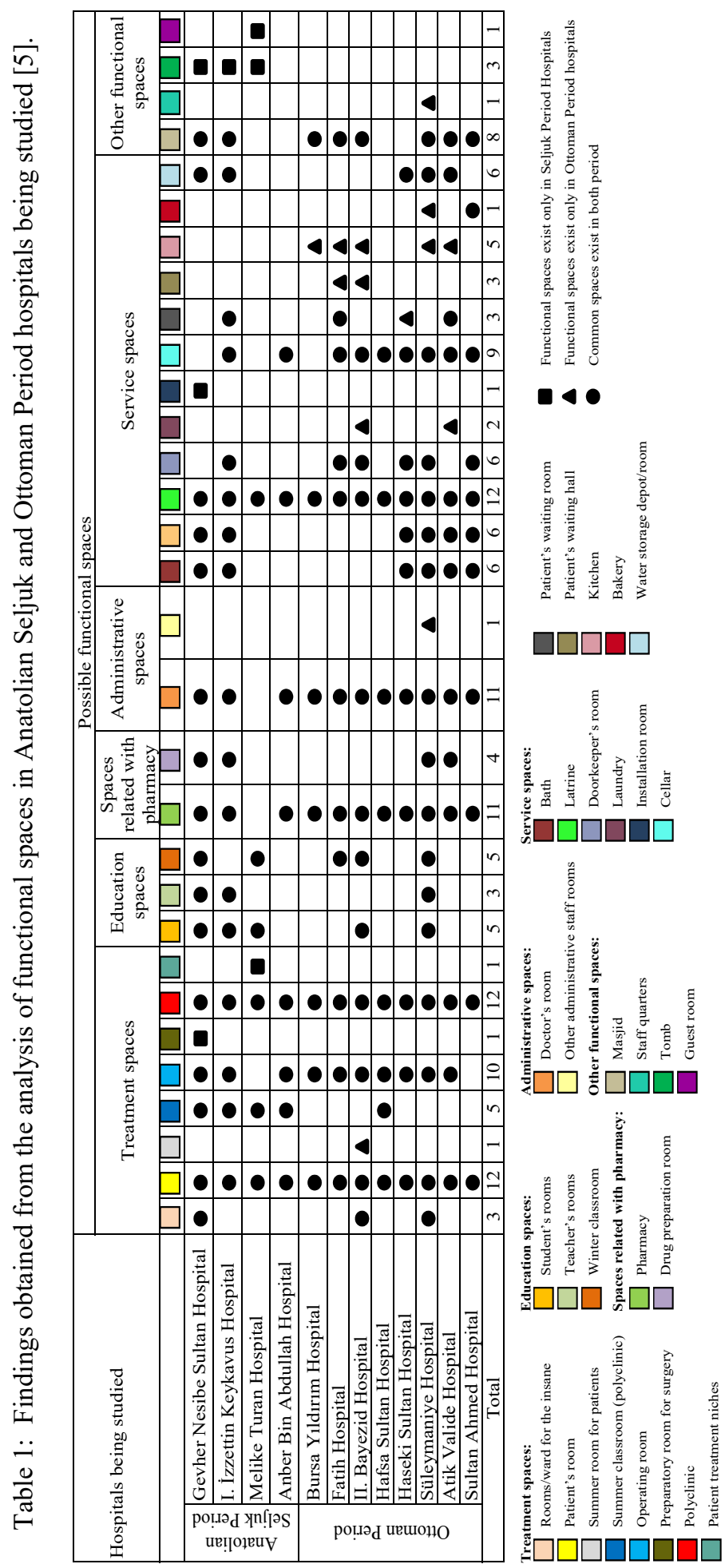




\section{FURNISHING DESIGN IN ANATOLIAN SELJUK AND OTTOMAN HOSPITALS}

Furnishings, fixtures, and equipment such as built-in and moving furniture, lighting and heating fixtures, drawers and racks, books, and kitchen fixtures are called as unstructured elements of a building either designed by architects, engineers or located by the users or owners of the building [10]. Documentation and inventory of historic furnishings, fixtures, and equipment of old buildings is a rarely studied research area that the researchers give importance.

Among these historic buildings, Anatolian Seljuk and Ottoman period hospitals were places constructed both for the treatment and educational purposes. Miniatures and archival documents give detailed information on the furnishing design of functional spaces of those mentioned hospitals. By means of these contributory documents it is possible to determine that the functional spaces were furnished properly according to the needs of the time in their construction. By examining the waqf deeds of the hospitals, it is understood that most of the revenues of the waqf were spent for the construction, maintenance, repair, and cleaning of the hospitals as well as for the wages of the staff. In addition, by examining the old accounting records it is possible to determine the waqf revenues to be spent for purchasing furnishing and some other essential needs for the hospital such as carpets, rugs, bags, carpetbags, mats, oil, oil lamps, and canvas [11]. Similarly, in some parts of the waqf deeds belonging to the hospitals being studied, there is much information on daily amounts and prices of such goods as oil lamps, oil, candles, mats, and brooms. For instance, in waqf deed of the Fatih Mosque Complex, daily prices of above mentioned goods were written in details [12].

In Ottoman period, there were also registers on purchasing of carpets and rugs for the religious and social building such as mosques, hospitals, soup kitchens. For instance, accounting records dated 1490 belonging to the Edirne II. Beyazid Mosque Complex show that some of the revenues of the waqf deed must have been used for purchasing canvas, rugs, carpets, bags, and carpetbags to be used for soup kitchen, madrasah, and hospital buildings. In other words, a separate budget must have been reserved for the permanent fixtures and equipment such as firewood, candle, oil lamp, censer, pot, bowl, tray, broom, mat, pillow, carpet, mattress, lectern, and cloth [13] (Fig. 5 and Fig. 6). In Madrasah section of the hospital, two carpets, 46-48 books kept in a coffer, firewood, and oil lamp were registered, and in hospital section, special chains to tie the insane, 30 mattresses, 30 duvets, 64 pillows, 8 pots, 2 bowls, 2 big pots, 2 water jugs, 16 buckets, 2 trays, 6 cups, and 15 small flasks for sprinkling rose water were registered as permanent fixtures and equipment [13]. Mat, oil lamp, firewood, pillow and duvets might have been bought by students themselves without registered in official documents [13].

In addition, from the accounting records dated 1489-90 belonging to the Fatih Mosque Complex, it was written that mats and carpets were to be bought in order to be used for the hospital, madrasah and soup kitchen [11]. Rahl, candlestick, censer, and coffin were also among the goods devoted, in addition to the furnishing goods as mats, rugs, and carpets [11], [14]. For instance, in a waqf deed dated 1748 belonging to Ottoman fellow Haci İbrahim Pasha, for the mosque built on the parcel in Cifte Hamam neighbourhood in the province of Erzurum, "two prayer rugs, one green prayer rug, a small prayer rug, a cushion, ten decorated big carpets, four decorated small carpets, and twenty mats to be laid under those carpets" were counted among the furnishing equipment [14]. Similarly, in a waqf deed dated 1280 belonging to the Sivas Gök Madrasah, it was obliged to purchase an ewer for cleaning and ablution purposes [15]. Nonetheless it is not possible to find such useful details in all waqf deeds, the reasonable explanation of which might be that such kind of furnishing expenses were relatively low cost and mostly met through donations by charitable bodies [11]. 


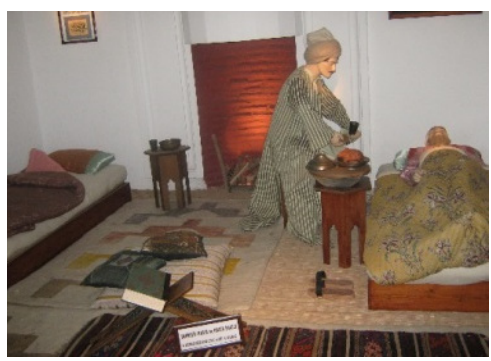

(a)

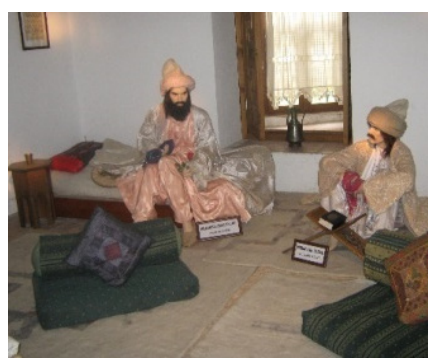

(b)

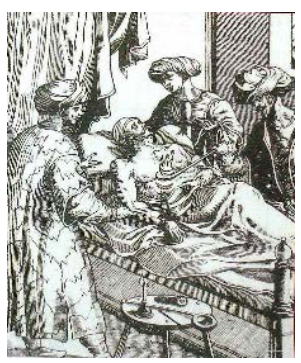

(c)

Figure 5: (a) and (b) Illustrations of patients' rooms in the Edirne II. Bayezid Hospital; (c) An illustration of Ottoman physcians treating a patient in the 16th century [6], [7].

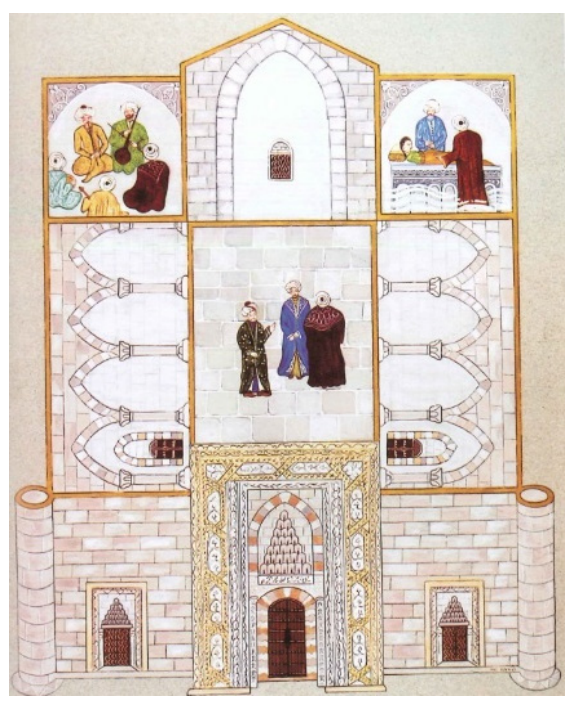

(a)

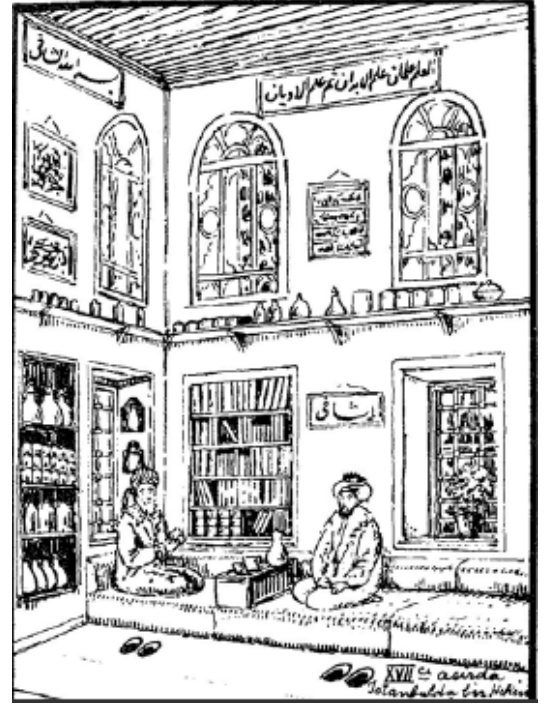

(b)

Figure 6: (a) Depiction of the Amasya Anber Bin Abdullah Hospital, drawn by İnci Özen; (b) An illustration of a physician's room belonging to the 17th century. (Drawn by Prof. Dr. Suheyl Unver [19], [20].)

It is also possible to get some information on inpatients' clothes by means of several traveller's accounts. For instance, a seventeenth century Turkish traveller Evliya Çelebi, gave some notable detailed information on the clothes of inpatients staying at Fatih Hospital, in which the bedsteads of the patients were made of walnut tree [16], [17]. He stated that "they had richly embroidered silk cloth with silver thread" [16].

As a main source of the information on furnishing, in addition to hospitals there were also some special consulting rooms called "doctor's store" which could be opened only with the permission of a chief physician. Those doctor's stores also functioned as pharmacies [6], [18]. 
Furnishing design of these doctor's stores have been also important sources in order to understand better the furnishing design in the hospitals.

Köker states that in the Gevher Nesibe Hospital and the Medicine Madrasah, in patient treatment rooms there was a bell on one side of patient's bed in order to call the other patient and there was an oil lamp on the other side in order to illuminate the space. There was also an ewer and a washbowl in patient treatment rooms for doctors for washing their hands after treatment [21].

In hospitals, there were some staff called "jameyus" who were responsible for cleaning the cloths of patients and other dirty sheets and cloths and such stuff. For instance, in waqf deeds and archival registers belonging to the Amasya Anber bin Abdullah Hospital, Bursa Yıldırım Hospital, Fatih Hospital, Haseki Hospital, Atik Valide Hospital and Süleymaniye Hospital, staff responsible for cleaning the dirty clothes had been mentioned. Similarly, in the Edirne II. Bayezid Hospital, there was a special functional space as laundry, for cleaning the cloths, but such a space is not observable in all hospitals being studied belonging to Seljuk and Ottoman periods. Instead, open courtyards of the hospitals might have been used for cleaning and drying of clothes. As İmamoğlu stated, cleaning the clothes was rather an inconvenient work in the old houses of Anatolian province of Kayseri, such that people had to carry water from the taps of fountains located in long-distances because the water of the wells in courtyards was rather hard. They boiled this water with the clothes and they were dried on the ropes spread on the flat roof or through the courtyards [22]. Similarly, in historic hospitals, there might have been large pans, boilers for washing clothes and ropes to hang out the laundry used by the staff responsible for cleaning the dirty clothes, sheets and other dirty stuff.

In waqf deed of the Edirne II. Beyazit Hospital, the furnishings in patients' rooms have been described as follows: 30 mattresses, 30 duvets, and 64 pillows [9], [23]. In this waqf deed dated 1486 the duties of the servant had been described as sweeping the madrasa, lying out the carpets and mats, cleaning the toilets, and lighting the oil lamps [9]. In an archival register dated 1847 belonging to the Bezmialem Valide Sultan Gureba Hospital, it was written that the duvets and beds of the patients were to be adjusted according to the seasonal conditions, also cleaning and arrangement of beds were to be done in accordance with the recommendations by hospital managers, doctors and chief physicians [9].

Furthermore, in the accounting records of a hospital dated 1490, shirts for surgeons and sherbet makers, cotton for patients and surgeons, apron for servants, nightshirts, and pearl were among the goods registered as expense items of the hospital [23]. Similarly, for the Edirne II. Beyazıt Hospital well-known traveller Evliya Çelebi quoted the followings [24]; "In some of the rooms, in winter days the patients, leaning to silk pillows and sitting on the mattresses and duvets embroidered with silver thread, wail towards the fire lightened inside the room. And in some of the rooms in spring days, season of insanity, the insane were fastened to golden or silver chains in their rooms".

Those descriptions of Çelebi give some detailed information on furnishing design and goods used in those historical hospitals. Miniatures and gravures depicting hospitals also show that patients inside the hospitals either slept on mattresses lied directly on the ground or on a kind of a four-legged bedstead with a duvet and pillow inside and sit on wooden seats when they were in the courtyards (Fig. 7). Laundrymen called "jamayush" as stated above were responsible for washing patients' laundry, bedding and duvets [6]. By analyzing miniatures, it is also possible to get some additional information on the transfer of patients to the hospitals. The patients had been carried to the hospital with a wheeled vehicle, a wooden stretcher, or on the shoulders of another person (Fig. 8 and Fig. 9) [25]. 


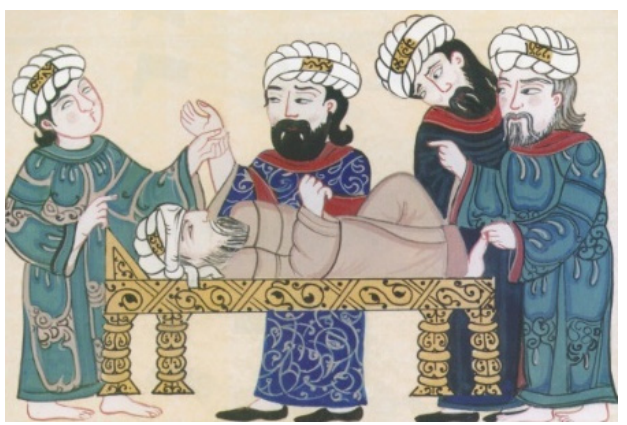

(a)

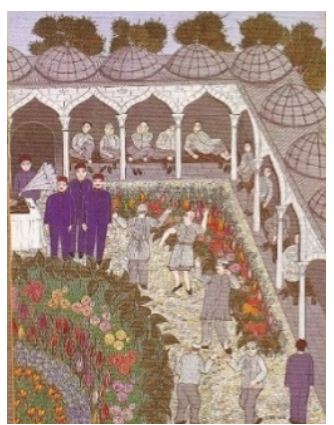

(b)

Figure 7: (a) An illustration of a patient lying on a four-legged bed; (b) Mental patients sitting on wooden seats in the courtyard of the Atik Valide Hospital. (Drawn by Ulker Erke [8], [25].)

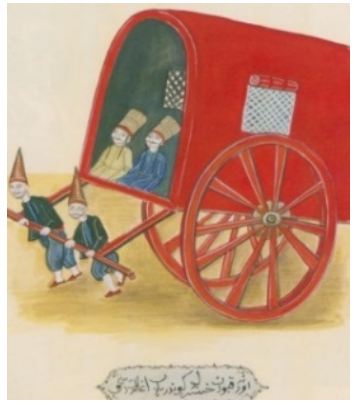

(a)

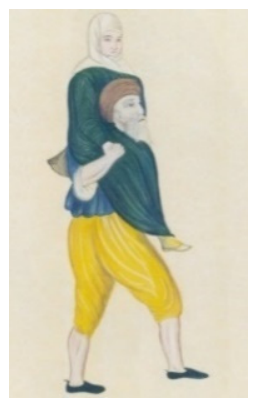

(b)

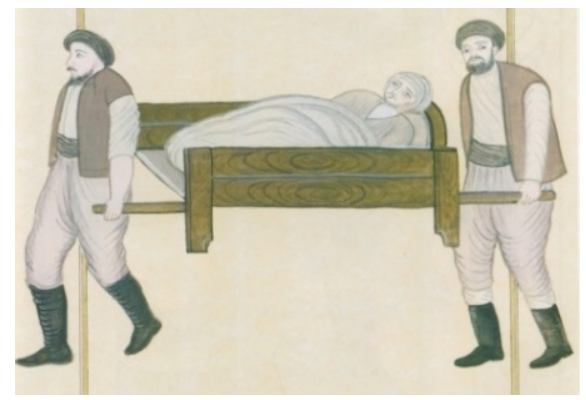

(c)

Figure 8: Illustrations showing transfer of patients to the hospital. (a) Transfer with wheeled vehicle; (b) On the shoulders; (c) Transfer on the stretcher. (Drawn by Ulker Erke [25].)

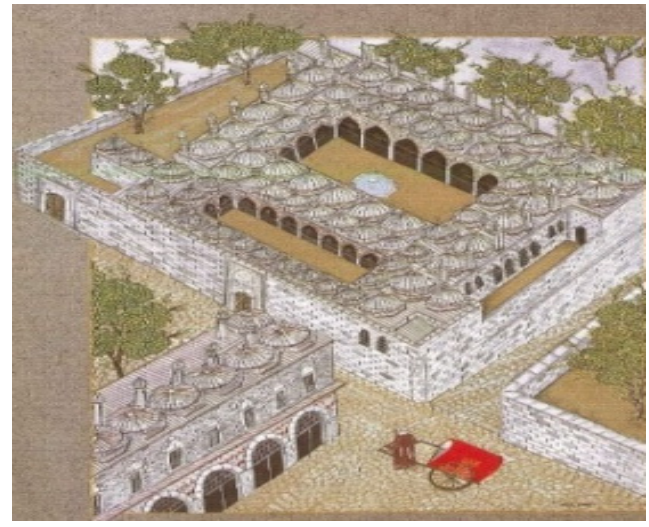

Figure 9: An illustration showing wheeled patient transfer vehicle in front of the Suleymaniye Hospital. (Drawn by Ulker Erke [8].) 


\section{CONCLUSIONS}

Furnishings, fixtures, and equipment as moving or built-in design elements in historic hospitals and possible functional spaces of these buildings collectively reflect their regional features and developmental stage in their own period as well Hence, in this article different functions of the spaces with their own original furnishing designs and interior fittings in some historical Anatolian hospitals, have been examined in a detailed manner.

In this respect, this research has provided a summary of in-situ observations and of archival and historical research results related to development of the functional spaces in the Anatolian historical hospitals. It revealed that there are both differences and similarities between Seljuk and Ottoman period in terms of functional space developments, their locations and numbers. Increasing demands and technological developments in time, caused differentiation in functional spaces especially in Ottoman period such that different spaces were designed for almost all different functions in this period's hospitals. Some of the functional spaces observed in Seljuk period cannot be observable in Ottoman ones, on the other hand new ones were added in that period. The research has also clearly "demonstrated that functional spaces were wisely planned as ideal models of Ottoman architecture" [4].

Furniture itself is an important component of collective memory revealing the conditions of its period [26]. Yet, researches on history of furniture in different historical buildings is rather rare let alone in historical hospitals. Waqf deeds and archival documents, as well as travellers accounts were important sources referred during the research. While furnishing design revealed by this research as a means of mentioned primary sources gave only a limited information about the subject, it can be evaluated as a beginning step of such researches in the future. Because, it is still important creating awareness among the researchers to make them evaluate applicability and adjustment of those historic furnishing designs observable in historical hospitals and in modern ones.

\section{ACKNOWLEDGEMENTS}

I am grateful to Prof. Dr. Zühal Özcan, my advisor of dissertation studies, this article being a part of it. In addition, Prof. Dr. M. Can Hersek and Prof. Dr. Z. Gediz Urak deserve special thanks for all their helpful advices and directions during my $\mathrm{PhD}$ studies.

\section{REFERENCES}

[1] Kazancıgil, R. \& Gökçe, N., The Edirne II. Bayezid Darüşşifa. The Şifahanes of Philanthropic Monuments of the Seljuk and Ottoman Eras, ed. A. Kılıç, Bilnet Printing House: Istanbul, pp. 217-237, 2015.

[2] Pakbaz, R., Naggaşi-e İran Az Dirbaz Ta Emruz, Zerrin ve Simin Publishing: Tahran, p. $166,1380 \mathrm{H}$.

[3] Cantay, G., Anadolu Selçuklu ve Osmanlı Darüşşifaları, Atatürk Kültür Merkezi Yayınları: Ankara, 1992.

[4] Dişli, G., Planning of functional spaces in Ottoman Period hospitals (darüşşifa) of Anatolia. Al-Masaq: Journal of the Medieval Mediterranean, 27(3), pp. 253-276, 2015.

[5] Disli, G., Anadolu Selçuklu ve Osmanlı Darüşşifalarında İşlevsel Sistemlerin ve Koruma Ölçütlerinin İrdelenmesi, PhD dissertation, Gazi University, Ankara, Turkey, (in Turkish), pp. 27-45, 145-187, 2014.

[6] Altıntaş, A., Medicine and darüşşifas in the Anatolian Seljuk and Ottoman Empires. The Sifahanes of Philanthropic Monuments of the Seljuk and Ottoman Eras, ed. A. Kılıç, Bilnet Printing House: Istanbul, pp. 21-59, 2015.

[7] Photo Archives of the Author, 2011. 
[8] Erke, Ü. \& Sarı, N., (eds), Historical Health Institutions in Turkey Through Ulker Erke's View and Style, $38^{\text {th }}$ International Congress on History of Medicine, Nobel Matbaacilık: İstanbul, p. 13, 48, 56, 61, 2002.

[9] Archives of Directorate General of Foundations.

[10] İpek, C., Deprem etkisi altindaki yapisal olmayan sistemlerin incelenmesi. Presented at $5^{\text {th }}$ International Earthquake Symposium, Kocaeli, Turkey, pp. 187-199, 2015.

[11] Deniz, B., Bir vakıf eser olarak cami, mescit, zaviye, şifahane gibi dini ve sosyal yapılarda bulunan halı kilim ve düz dokuma yaygılar ve bunların günümüzdeki durumu. Vakıflar Dergisi, 23, pp. 283-296, 1994.

[12] Ünver, S., Fatih külliyesine aid diğer mühim bir vakfiye. Vakıflar Dergisi, 1, pp. 3945, 1938.

[13] Müderrisoğlu, F., Edirne II. Bayezid Külliyesi. Vakıflar Dergisi, 22, pp. 151-198, 1991.

[14] Ateş, İ., Hayri ve Sosyal Hizmetler Açısından Vakıflar, Vakıflar Dergisi, 15, pp. 5588, 1982.

[15] Durukan, A., Anadolu Selçuklu sanatı açısından vakfiyelerin önemi, Vakıflar Dergisi, 26, pp. 25-44, 1997.

[16] Danışman, Z., Evliya Çelebi Seyahatnamesi 2, Zuhuri Danışman Yayınevi: İstanbul, p. 17, 24, 1970.

[17] Gökay, K., Ruh hekimliği sahasında türklerin ve vakıf müessesesinin hizmetleri, Vakıflar Dergisi, 2, pp. 263-265, 1942.

[18] Çetin, O., Illk Osmanlı Hastanesi, Bursa Yıldırım Darüşşifası (Bursa Mahkeme Sicillerine Göre), Göz Nurunu Koruma Vakfi Yayınları: İstanbul, p. 65, 2006.

[19] Sarı, N., Mesara, G. \& Kurt, Ü. E., (eds), Amasya Selçuklu ve Osmanlı Mimarisi ve Bezemeleri, Ord. Prof. Dr. A. Süheyl Ünver Nakışhanesi Yorumuyla, Karakter Color: İstanbul, p. 31, 2007.

[20] Sar1, N., Educating the Ottoman physician, Foundation for Science Technology and Civilisation Limited, L. Ball (ed.), Aug. 2005, pp. 1-21, 2005.

[21] Köker, A.H., Gevher Nesibe T1bbiyesi'nde çalışan hekim ve müderrisler. Presented at Selçuklular Devrinde Kültür ve Medeniyet, Gevher Nesibe Sultan Adına Düzenlenen Selçuklu Gevher Nesibe Sultan Tip Fakültesi Kongresi, Kayseri, Turkey, pp. 49-56, 1991.

[22] İmamoğlu, V., Geleneksel Kayseri Evleri, Traditional Dwellings in Kayseri, Halkbank Kültür Yayınları: Ankara, pp. 85-86, 1992.

[23] Şengül, E., Kültür Tarihi İçinde Müzikle Tedavi ve Edirne Sultan II. Bayezid Darüşşifas1, Master's thesis, Trakya University, Edirne, Turkey, p. 100, 161,170, 2008.

[24] Danışman, Z., Evliya Çelebi Seyahatnamesi 6, Zuhuri Danışman Yayınevi: İstanbul, pp. 20-23, 1970.

[25] Erke, Ü. \& Sarı, N., (eds), Turkish Medical History Through Miniature Pictures Exhibiton, 38th International Congress on History of Medicine, Nobel Matbaacilık: İstanbul, p. 152, pp. 154-156, 2002.

[26] Ultav, Z. T., Hasırc1, D., Atmaca, H. \& Borval1, S., Türk modern mobilyasinin peşinde, Selçuk-Teknik Dergisi, Special Issue-1 (UMK-2015), pp. 480-497, 2015. 